\title{
Genetic variation of four populations of the Little Blue Penguin, Eudyptula minor
}

\author{
Meredith A. M. Meredith and \\ Frank Y. T. Sin*
}

Department of Zoology, University of Canterbury, Christchurch 1, New Zealand.

\begin{abstract}
The biochemical differentiation of four geographic populations of the Little Blue Penguin, Eudyptula minor from Onawe Peninsula, Motunau Island, Maud Island (South Island of New Zealand) and Poor Knights Island (North Island) was determined. Ten isozymes, with a total of 24 loci were analysed. Seven of these loci were polymorphic. A south-north cline was detected in the allelic frequencies of all the polymorphic loci. Population specific loci were detected. The Yellow-eyed Penguin, Megadyptes antipodes offered a comparison between genera. In Megadyptes only two loci were polymorphic, and it had a lower mean heterozygosity than $E$. minor. Loci specific for this genus were detected. The two genera shared the same alleles at seventeen of twenty loci.
\end{abstract}

\section{INTRODUCTION}

There are a number of characteristics which distinguish the Little Blue Penguin, Eudyptula minor, from the other penguins. They are small, blue dorsally, and white ventrally, without any tufts or flashes. They are found only in Australasia. In New Zealand, E. minor is widely distributed along the coast and around the offshore islands. The coastal populations are presently subdivided into subspecies on the basis of external morphological characteristics proposed by Kinsky and Falla (1976). They give to White-flippered Penguin of the Canterbury coast the name E.m. albosignata; the North Island population E.m. iredalei; and the Cook Strait birds E.m. variabilis.

The present study attempts to determine the amount of genetic variation in these geographical populations of E. minor which are morphologically distinct according to (Kinsky and Falla, 1976).

\section{MATERIALS AND METHODS}

\section{Study areas}

The four E. minor study areas were (1) Onawe Peninsula $\left(43^{\circ} 46^{\prime} \mathrm{S}, 172^{\circ} 55^{\prime} \mathrm{E}\right)$, situated approximately $30 \mathrm{~km}$ south-east of Christchurch in the

\footnotetext{
* Author to whom correspondence should be addressed.
}

Akaroa Harbour; (2) Motunau Island $\left(43^{\circ} 08^{\prime} \mathrm{S}\right.$, $\left.173^{\circ} 10^{\prime} \mathrm{E}\right)$, about $1 \mathrm{~km}$ offshore and $64 \mathrm{~km}$ north of Christchurch; (3) Maud Island (41 $\left.{ }^{\circ} 01^{\prime} \mathrm{S}, 173^{\circ} 52^{\prime} \mathrm{E}\right)$ in the Marlborough Sounds; and (4) Poor Knights Islands $\left(35^{\circ} 30^{\prime} \mathrm{S}, 174^{\circ} 45^{\prime} \mathrm{E}\right)$, approximately $24 \mathrm{~km}$ off the east coast of Northland (North Island). One population of Yellow-eyed Penguins ( Megadyptes antipodes) was sampled from Otago Peninusla $\left(45^{\circ} 54^{\prime} \mathrm{S}, 170^{\circ} 37^{\prime} \mathrm{E}\right)$.

The population, sample sizes and the time sampled are given in table 1.

\section{Penguin handling and sexing}

The penguins were caught at night on their breeding grounds and placed in a bag with a hole, which allowed a leg to protrude while blood was extracted. Only adult penguins were sampled.

The method described by O'Brien (1940) to distinguish the sexes by bill characteristics was used in this study. Difficulty in differentiating between juvenile males and adult females was sometimes experienced, in which case penguins were classified as juveniles. Those penguins found cohabiting were assumed to be adult male/female pairs, since two birds of the same sex seldom occupy the same burrow except in the moulting season (C. Challies, personal communication). Fledglings were easily identified by their smaller size and paler plumage. 
Table 1 Sampling data

\begin{tabular}{|c|c|c|c|c|}
\hline Scientific name & Vernacular name & $\begin{array}{l}\text { Sample } \\
\text { size }\end{array}$ & Location & Month/Year \\
\hline Eudyptula minor albosignata & White-flippered penguin & $\begin{array}{r}15 \\
73 \\
10 \\
3 \\
8 \\
7 \\
45\end{array}$ & $\begin{array}{l}\text { Onawe Peninsula } \\
\text { Onawe Peninsula } \\
\text { Onawe Peninsula } \\
\text { Onawe Peninsula } \\
\text { Onawe Peninsula } \\
\text { Onawe Peninsula } \\
\text { Motunau Island }\end{array}$ & $\begin{array}{l}\text { Dec } 1981 \\
\text { Feb } 1982 \\
\text { Apr } 1982 \\
\text { Jun } 1982 \\
\text { Aug } 1982 \\
\text { Oct } 1982 \\
\text { Dec/Jan } 1981 / 82\end{array}$ \\
\hline E. minor iredalei & Northern blue penguin & 43 & Poor Knights Is. & Nov 1981 \\
\hline E. minor variabilis & Cook Strait blue penguin & 41 & Maud Island & May 1982 \\
\hline Megadyptes antipodes & Yellow-eyed penguin & 27 & Otago Peninsula & Feb 1983 \\
\hline
\end{tabular}

\section{Blood sampling and preparation}

Two $1 \mathrm{ml}$ samples were drawn from either the anterior tibial (leg) or anterior digital (foot) vein of most individuals through 21 gauge hypodermic needles into sterile disposable syringes (Monoject, USA). The first samples were drawn into syringes containing $0.05 \mathrm{ml}$ of $0.2 \mathrm{M}$ disodium ethylene diamine tetra-acetate (EDTA); each $50 \mathrm{ml}$ of EDTA stock containing $10 \mathrm{mg}$ Thiomersal-a bacterial inhibitor. The other samples were drawn into syringes containing $0.05 \mathrm{ml}$ of $0.2 \mathrm{M}$ Heparin (Lithium salt). Once drawn, samples were carefully mixed with the anticoagulant and withdrawn into sterile $1.5 \mathrm{ml}$ Eppendorf centrifuge tubes and stored on ice until centrifuged. As soon as possible, whole blood samples were centrifuged at $1500 \mathrm{rpm}$ for $10 \mathrm{~min}$. The plasma fraction was removed and frozen in Eppendorf tubes in liquid nitrogen held in a 201 container with a 20 day static holding time. Red cells were washed three times in physiological saline $(0.9$ per cent $\mathrm{NaCl})$ before freezing. The penguins from Onawe Peninsula were banded to allow blood to be resampled at differing times during the year. This was undertaken to test for seasonal variations in the proteins and enzymes.

\section{Preparation of samples for electrophoresis}

All samples were thawed slowly at $4^{\circ} \mathrm{C}$. After use, they were immediately refrozen in liquid nitrogen. Enzymes were extracted from three blood fractions: plasma, erythrocytes and leukocytes. Every sample was mixed with a small quantity of Bromophenol Blue in buffer $H$ (see table 2) before electrophoresis. The following processes were used to extract the proteins and enzymes from each blood fraction. (a) Plasma fraction The untreated plasma samples were used for electrophoretic analysis.

(b) Leukocyte fraction Leukocyte samples were suspended in distilled water and leukocyte lysates were obtained by repeated freezing and thawing.

(c) Erythrocyte fractions Erythrocyte samples were haemolysed using one of three methods, depending on the enzyme to be extracted.

(i) Packed red cells were suspended in an equal volume of distilled water, then frozen and thawed once.

(ii) As above, with 1 per cent $(\mathrm{v} / \mathrm{v})$ Triton $\mathrm{X}-100$ added to the distilled water.

(iii) As in (i), with 1 per cent (v/v) Toluene added to the distilled water.

Erythrocyte lysates were centrifuged in an Eppendorf SP 1500 for 10 minutes immediately after lysis.

For the analysis of glucose-6-phosphate dehydrogenase $(G 6 P D H)$, it was necessary to isolate this enzyme from the red blood cells which were lysed using one volume of red cells to 20 volumes of distilled water. The lysate was centrifuged at $18,400 \times \mathrm{g}$ and the resulting supernatant discarded. The sediment was mixed with an equal volume of $0.05 \mathrm{M}$ phosphate buffer $(p \mathrm{H} \mathrm{6.5)}$ containing 2 per cent $(\mathrm{v} / \mathrm{v})$ Triton $X-100$ and 2 per cent $(\mathrm{v} / \mathrm{v}) 2$ mercaptoethanol. This solution was left to stand for 20 minutes at room temperature, with occasional shaking. After 20 minutes, the solution was centrifuged at $18,400 \times \mathrm{g}$ and the supernatant brought up to 60 per cent of saturation with ammonium sulphate $(3.61 \mathrm{~g}$ in $10 \mathrm{ml})$. The resultant solution was centrifuged for $15 \mathrm{~min}$ and the insoluble component that formed on the surface of the solution removed. All three fractions (i.e., 
sediment, supernatant and the surface component) were tested for $G 6 P D H$ activity. The region of highest activity was the insoluble component that formed on the surface of the supernatant. This insoluble component was redissolved in an equal volume of $0.05 \mathrm{M}$ phosphate buffer containing 2 per cent $(\mathrm{v} / \mathrm{v})$ 2-mercaptoethanol and stored frozen until used.

A considerable amount of enzyme degradation was encoutered. Red cell lysates that were released using Triton X-100 were used only once; toluene treated samples could be used twice and all other samples used four times before breakdown of enzymes was obvious.

The buffer systems used for electrophoresis and for the staining of the soluble proteins and enzymes are given in tables 2 and 3 .

Ten isoenzymes were studied, 5 from group 1 (specific enzymes), and 5 from group 2 (nonspecific enzymes) (Gillespie and Kojima, 1969) (table 4).

Blood collected in vessels containing EDTA as the anticoagulant was used for all enzymes except acid and alkaline phosphatases, which were analysed using blood extracted with Heparin.

\section{Stain recipes}

Detection of isozymes was essentially as described previously (Brewer, 1970; Harris and Hopkinson, 1976; Shaw and. Prasad, 1970).
Table 2 Buffers used for electrophoresis and stains

\begin{tabular}{|c|c|}
\hline A & $\begin{array}{l}0.1 \mathrm{M} \text { Tris } / 0.1 \mathrm{M} \text { Maleic acid } / 0.1 \mathrm{M} \text { Magnesium } \\
\text { chloride-adjusted to } p \mathrm{H} 9.0 \text { with } 10 \mathrm{~N} \mathrm{NaOH}\end{array}$ \\
\hline B & $0 \cdot 1 \mathrm{M}$ Tris $/ 0 \cdot 1 \mathrm{M}$ Glycine- $p \mathrm{H} 8 \cdot 2$ \\
\hline $\mathrm{C}$ & $0.25 \mathrm{M}$ Tris $/ 0.1 \mathrm{M}$ Citric acid- $p \mathrm{H} 8.6$ \\
\hline $\mathrm{D}$ & 0.9 M Tris $/ 0.5$ Boric Acid $/ 0.02$ M EDTA $-p$ H 7.5 \\
\hline $\mathrm{E}$ & $0.11 \mathrm{M}$ Trisodium citrate $/ 0.24 \mathrm{M} \mathrm{NaH}_{2} \mathrm{PO}_{4}-p \mathrm{H} 6.2$ \\
\hline $\mathrm{F}$ & $0.07 \mathrm{M}$ Boric Acid adjusted to $p \mathrm{H} 9.3$ with $10 \mathrm{~N} \mathrm{NaOH}$ \\
\hline G & $0.1 \mathrm{M} \mathrm{NaH}_{2} \mathrm{PO}_{4}$ adjusted to $p \mathrm{H} 7.0$ with $1 \mathrm{M} \mathrm{Na}_{2} \mathrm{HPO}_{4}$ \\
\hline $\mathrm{H}$ & $0.25 \mathrm{M}$ Tris adjusted to $P \mathrm{H} 7.0$ with $1 \mathrm{~N} \mathrm{HCl}$. \\
\hline
\end{tabular}

\section{Genetic interpretation}

Enzyme followed by a number, e.g., EST-1, EST-2, indicating the bands anodal migration, where EST2 is the more anodal band. Allelic variants were designated by a superscript after the locus number, e.g., EST $-1^{s}$ and $E S T-1^{f}$ where $s$ indicates slow moving and $f$, fast moving bands.

The phenotypic frequencies of the populations were then tested against the Hardy-Weinberg equilibrium using the Chi-squared $\left(\chi^{2}\right)$ test of goodness of fit, with $1 / 2\left(n^{2}-n\right)$ degrees of freedom, where $n=$ number of alleles (Ferguson, 1980). The effective number of alleles per locus; the mean heterozygosity per locus $(H)$; and the proportion of polymorphic loci were determined.

Table 3 Summary of methods for electrophoresis of 10 enzymes

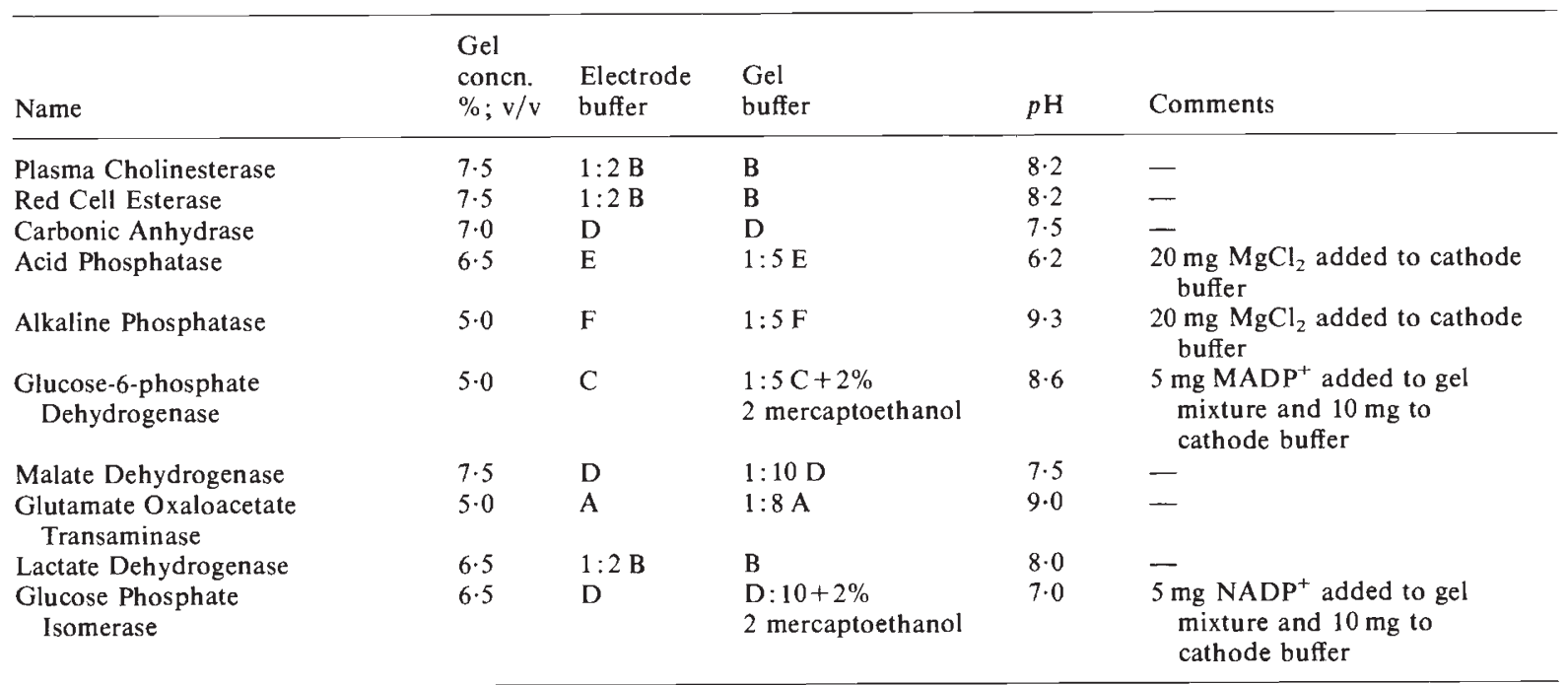


Table 4 Enzymes and blood fractions used for this study

\begin{tabular}{lll}
\hline $\begin{array}{l}\text { Enzyme } \\
\text { E.C. no. }\end{array}$ & Enzyme or protein & \\
\hline 3.1 .1 .8 & Cholinesterase $(E S T)$ & Blood fraction \\
3.1 .1 .1 & Red cell esterase $(E S T)$ & Plasma \\
3.1 .3 .1 & Acid Phosphatase $(A c P)$ & Red blood cells \\
3.1 .3 .1 & Alkaline Phosphatase $(A L P)$ & Red blood cells \\
4.2 .1 .1 & Carbonic Anhydrase $(C A)$ & Plasma \\
1.1 .1 .27 & Lactate Dehydrogenase $(L D H)$ & Red blood cells \\
1.1 .1 .49 & Glucose-6-phosphate Dehydrogenase $(G 6 P D H)$ & Red blood cells \\
2.6 .1 .1 & Glutamate oxaloacetate Transaminase & Red blood cells \\
& (mitoch \& soluble) $\left.G O T_{m}+G O T_{s}\right)$ & White blood cells \\
5.3 .1 .9 & Glucose Phosphate Isomerase $(G P I)$ & Red blood cells \\
1.1 .1 .37 & Malate Dehydrogenase $(M D H)$ & Red blood cells \\
& Malic Enzyme $(M E)$ & Red blood cells \\
\hline
\end{tabular}

The normalised identify of genes (I) between populations was calculated using Nei's index and the mean genetic distance (D) between two populations was calculated (Nei, 1972).

\section{RESULTS}

Ten enzymes, with a total of 24 loci, were analysed. The allelic frequencies for all the loci are given in table 5 .

\section{Plasma EST}

Three zones of plasma EST activity were detected in penguin plasma. All three zones had banding patterns characteristic of monomeric enzymes with two co-dominant alleles. Thus, they were assumed to be coded for by three distinct loci, designated $E S T-1, E S T-2$ and $E S T-3$, respectively. The allelic variants were designated $E S T-1^{s}, E S T-1^{f}, E S T-2^{s}$, $E S T-2^{f}, E S T-3^{s}, E S T-3^{f}$. Over all EST loci, the slow allelic variants showed the highest frequencies. The EST-1 and EST-3 loci showed South to

Table 5 Allelic frequencies for the five penguin populations

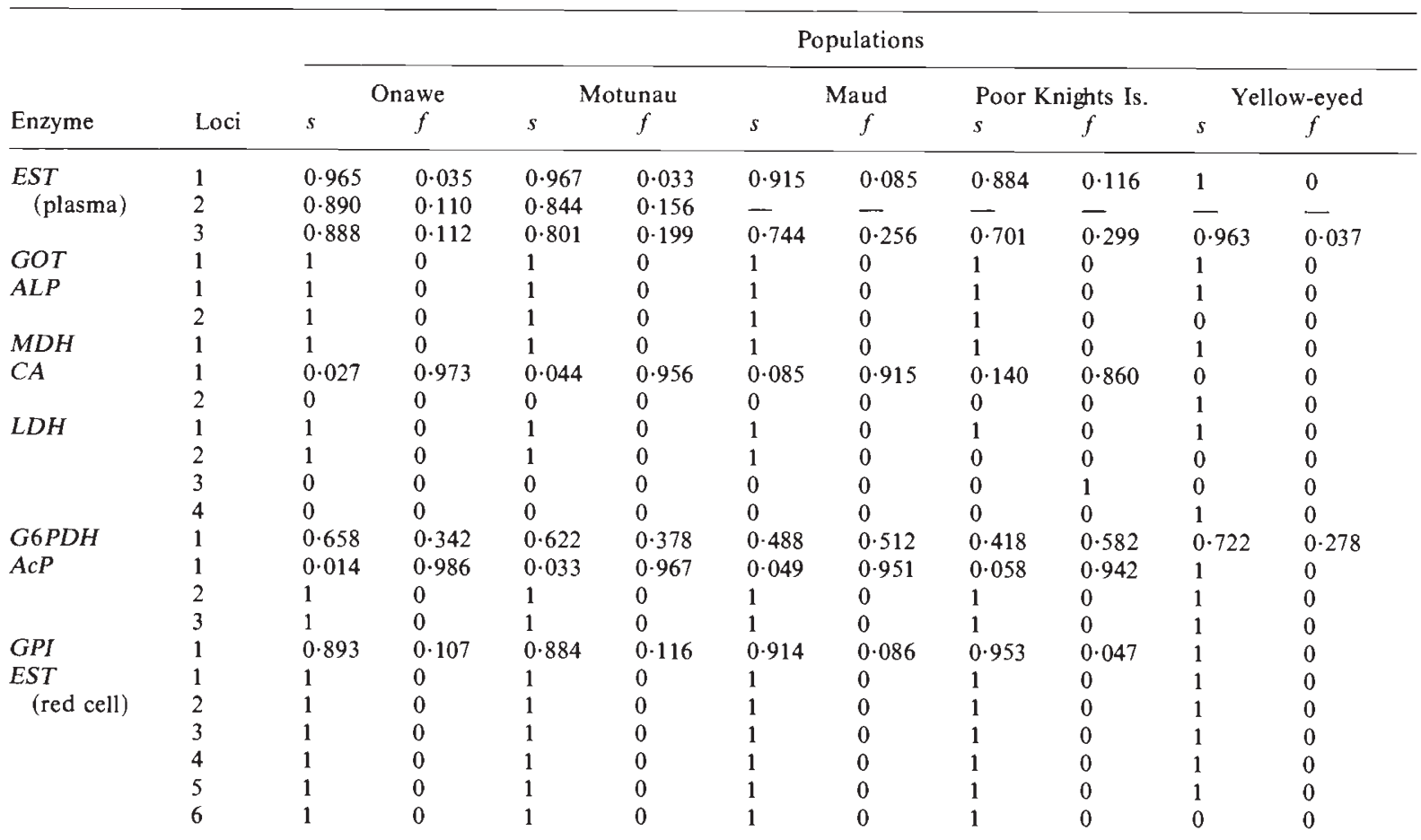


North variation in the allelic frequencies over the four E. minor populations. The frequency for the slow $(s)$ alleles decreased as the populations moved from the southernmost Onawe Peninsula population to the northernmost Poor Knights Islands population.

EST-2 was undetected in the Poor Knights Island and Maud Island populations of Little Blue Penguins and in the Yellow-eyed Penguin samples. Other inconsistently resolved bands were not scored.

\section{GOT}

The form found in penguin red blood cells was probably the soluble (GOTs) isozyme as only the reticulocytes in the blood exhibit the mitochondrial $($ GOTm) isozymes. One protein band with common mobility and GOT activity was detected in the blood of all five penguin populations.

\section{$A L P$}

Two protein bands with $A L P$ activity were detected in zymograms of the plasma of all populations of E. minor. These were considered to be the product of two distinct loci, designated $A L P-1$ and $A L P$-2. $A L P-1$, but not $A L P-2$, was detected in the plasma of Yellow-eyed Penguins.

\section{$M D H$}

Red cells of penguins showed one band with MDH activity. This locus was monomorphic and the same allele was shared by all five penguin populations. Other inconsistently resolved bands were not scored.

\section{$C A$}

One zone of $C A$ was detected in the red blood cells of all populations of E. minor. This was designated $C A-1$ and had a banding pattern characteristic of a monomeric enzyme with two co-dominant alleles, designated $C A-1^{s}$ and $C A-1^{f}$. The $C A-1^{f}$ alleles were present in all $E$. minor populations in the highest frequencies. This locus, also, showed a south/north cline in the allelic frequencies with increasing frequency for the fast $(f)$ allele from the southern to the northern populations.

One $C A$ band was found in the blood of Yellow-eyed Penguin, with an electrophoretic mobility differing from either allelic form of all the $E$. minor populations.

\section{$L D H$}

Zymograms of plasma $L D H$ showed a 5-banded pattern characteristic of a tetrameric enzyme with two co-dominant alleles, presumbly the products of two distinct loci ( $L D H-1$ and $L D H-2$ ).

Variants of the $L D H h$ loci were found in the Poor Knights (LDH-3) and the Yellow-eyed Penguin ( $L D H-4)$ populations.

\section{G6PDH}

One zone of enzymatic activity was seen in zymograms of penguin blood stained for $G 6 P D H$. This locus was polymorphic, showing a banding pattern characteristic of a dimeric enzyme with two co-dominant alleles, designated $G 6 P D H-1^{s}$ and $G 6 P D H-1^{f}$.

The G6PDH-1 ${ }^{s}$ allele was present in the highest frequencies in the Onawe Peninsula and Motunau Island populations whereas the G6PDH$1^{f}$ allele was present in greater frequencies in the Maud and Poor Knights Islands populations.

\section{AcP}

Three regions of $A c P$ activity were observed in zymograms of all the penguin populations. These were designated $A c P-1, A c P-2$ and $A C P-3 . A C P-1$ was a polymorphic locus, with two alleles. The allele $A c P-1^{f}$ was present in the greatest numbers in all penguin populations. The $s$ allele increased in frequency from the southernmost to the northernmost populations of E. minor. AcP-2 and $A c P-3$ were monomorphic.

\section{GPI}

One zone of $P G I$ activity was seen in zymograms of all populations of the penguins. This polymorphic locus showed a banding pattern characteristic of a dimeric enzyme with two co-dominant alleles, designated $G P I-1^{s}$ and $G P I-1^{f}$ respectively, with $G P I-1^{s}$ showing the highest allelic frequencies. The frequency of this slow allele increased from the southern to the northern populations.

\section{EST}

In the red cell fractions of the penguin blood, at least eight to nine protein bands showed EST activity but only six of these were consistently detected throughout the year. These were designated EST-1, EST-2, EST-3, EST-4, EST-5, and EST-6. EST-6 was not detected in the blood from the Yellow-eyed Penguin populations. 
All loci, except EST-2 of the Onawe Peninsula population $(P<0.001)$, were in Hardy-Weinberg equilibrium (table 6). The EST-2 locus had an excess of heterozygotes.

Table 7 summarises the genetic variation for the five penguin populations. Within the E. minor populations, the mean heterozygosity $(H)$ value was highest in the Onawe Peninsula population $(0 \cdot 47)$, the Poor Knights Islands population had the lowest value $(0 \cdot 34)$. The mean heterozygosity of the Yellow-eyed Penguin population was 0.16.

The effective number of alleles for each polymorphic locus (table 8) also showed a north/south trend, with EST-1, EST-3, CA-1, G6PDH-1 and $A C P-1$ values all increasing and the $G P I-1$ value decreasing from the Onawe Peninsula through the Motunau Island and the Maud Island populations to the Poor Knights Islands population of E. minor.

Nei's genetic identity and distance values, calculated from table 5, are given in table 9. The Onawe Peninsula and Motunau Island populations are the most similar, with an $I$ value of 0.999 . The pairwise comparisons between the Yelloweyed Penguin population and each of the other four populations showed the least similarities, with a mean $I$ value of $0 \cdot 818$. Maud Island compared to both Onawe Peninsula and Motunau Island populations were the second most similar, $I=$
0.977. The Poor Knights Islands population compared to the Maud Island population showed a genetic identity of 0.938 and compared to the Onawe Peninsula and Motunau Island populations showed genetic identities of 0.916 and 0.919 respectively.

\section{DISCUSSION}

An analysis of the allelic frequencies for the four geographic populations of $E$. minor revealed clinal variations in all the seven polymorphic loci. One of the most extreme cases is seen in the plasma EST-3 locus. The Onawe Peninsula population shows an allelic frequency for the slow allele to be 0.888 . The Poor Knights Island population, on the other hand, show the frequency of 0.701 . The Motunau Island population has a value of 0.801 , intermediate between the Onawe Peninsula and the Poor Knights Island values. In addition, the Maud Island frequency for the $s$ allele $(0.744)$ is intermediate between the Motunau Island frequency and the Poor Knights Island values.

The allele frequencies for the polymorphic loci of the Yellow-eyed Penguin are consistently closer to unity than those of $E$. minor. The mean number of alleles per locus for the four E. minor popula-

Table 6 Chi square values $\left(\chi^{2}\right)$ with levels of significance (in brackets) for the Hardy-Weinberg equilibrium test of genetic equilibrium at each locus

\begin{tabular}{|c|c|c|c|c|c|}
\hline \multirow[b]{2}{*}{ Loci } & \multicolumn{5}{|c|}{ Populations } \\
\hline & Onawe & Motunau & Maud & Poor Knights Is. & Yellowed-eyed P. \\
\hline EST 2 & $6.07(p<0.001)^{* * *}$ & $1.04(\mathrm{NS})$ & N/A & N/A & $1 \cdot 70(\mathrm{NS})$ \\
\hline EST 3 & $2 \cdot 24(\mathrm{NS})$ & $0.45(\mathrm{NS})$ & $1.88(\mathrm{NS})$ & $0 \cdot 26(\mathrm{NS})$ & $0.39(\mathrm{NS})$ \\
\hline $\mathrm{CA}$ & $2 \cdot 30(\mathrm{NS})$ & $1.81(\mathrm{NS})$ & $1 \cdot 14(\mathrm{NS})$ & $0 \cdot 04(\mathrm{NS})$ & $0.34(\mathrm{NS})$ \\
\hline$G P I$ & $2 \cdot 93(\mathrm{NS})$ & $0.01(\mathrm{NS})$ & $0.65(\mathrm{NS})$ & $0.95(\mathrm{NS})$ & $3.08(\mathrm{NS})$ \\
\hline
\end{tabular}

$\mathrm{NS}=$ not significant-locus in Hardy-Weinberg equilibrium. $p<0.001^{* * *}=$ significant-probability of $99.9 \%$ that locus is not in Hardy-Weinberg equilibrium.

Table 7 Summary of genetic variation

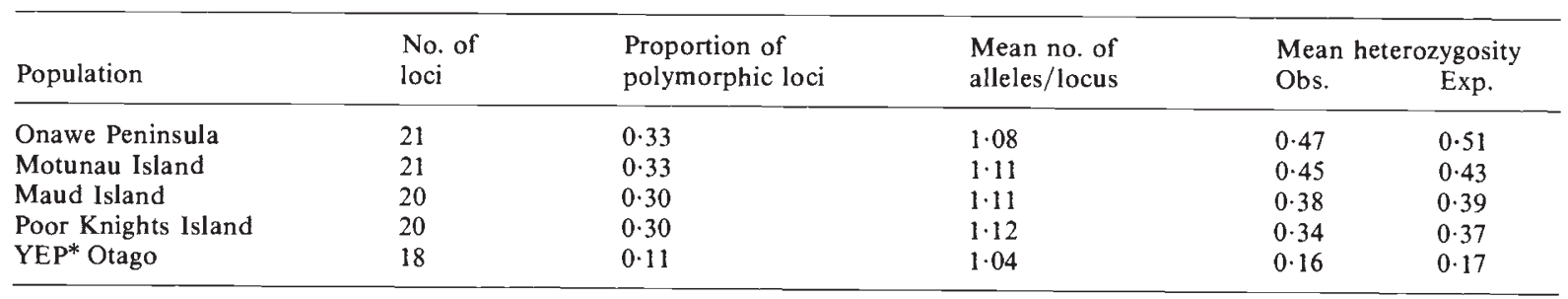

* YEP $=$ Yellow-eyed Penguin. 
Table 8 Effective number of alleles per polymorhpic locus

\begin{tabular}{|c|c|c|c|c|c|c|}
\hline Enzyme & Loci & Onawe & Motunau & Maud & Poor Knights & $\begin{array}{l}\text { Otago } \\
\left(\mathrm{YEP}^{*}\right)\end{array}$ \\
\hline \multirow[t]{3}{*}{$E S T$} & 1 & 1.07 & 1.07 & $1 \cdot 18$ & $1 \cdot 26$ & 1 \\
\hline & 2 & $1 \cdot 24$ & $1 \cdot 36$ & - & - & - \\
\hline & 3 & $1 \cdot 25$ & 1.47 & $1 \cdot 62$ & $1 \cdot 72$ & $1 \cdot 08$ \\
\hline$C A$ & 1 & 1.07 & 1.09 & $1 \cdot 18$ & $1 \cdot 32$ & 1 \\
\hline$G 6 P D H$ & 1 & $1 \cdot 82$ & $1 \cdot 89$ & $2 \cdot 00$ & $1 \cdot 95$ & $1 \cdot 67$ \\
\hline$A c P$ & 1 & 1.03 & 1.07 & $1 \cdot 10$ & $1 \cdot 12$ & 1 \\
\hline$G P I$ & 1 & $1 \cdot 24$ & $1 \cdot 26$ & $1 \cdot 19$ & $1 \cdot 10$ & 1 \\
\hline
\end{tabular}

* YEP $=$ Yellow-eyed Penguin.

Table 9 Nei's Genetic identity and distance values for the five penguin populations

\begin{tabular}{|c|c|c|c|c|c|}
\hline & Onawe & Motunau & Maud & Poor Knights Is. & $\begin{array}{l}\text { Otago } \\
\text { Yellow-eyed }\end{array}$ \\
\hline Onawe & & 0.999 & 0.977 & 0.916 & 0.803 \\
\hline Maud & 0.022 & 0.023 & & 0.938 & 0.828 \\
\hline Poor Knights Is. & 0.087 & 0.084 & 0.063 & & 0.828 \\
\hline Otago Yellow-eyed & $0 \cdot 213$ & 0.206 & $0 \cdot 189$ & $0 \cdot 188$ & \\
\hline
\end{tabular}

Genetic identity values in the upper triangle and genetic distance values in the lower triangle.

tions are very similar, but these values are all slightly higher than that of the Yellow-eyed Penguin.

The mean heterozygosity values of 0.041 for the four E. minor populations is similar to that calculated for other vertebrates. The mean heterozygosity from studies of birds has been calculated as 0.037 , and mammals 0.039 (Avise and Aquadro, 1982). When the heterozygosity of the four populations are examined, it is clear that the southern populations (Onawe Peninsula and Motunau Island) have a much higher heterozygosity value $(0.047$ and 0.045$)$ than the northern population (Poor Knights Islands), 0.034. Thus the southern populations are more polymorphic. This is consistent with the high intra-population variations detected in the southern populations by both the classical and numerical phenetic approaches (Meredith, 1984).

The mean heterozygosity $(0 \cdot 016)$ of the Yelloweyed Penguin is lower than values reported for all other bird species and the E. minor populations. This may be due to the absence of panmixia in the taxon, or the presence of null alleles. It is probably not due to selection against heterozygotes because all the loci studied in this genus appear to be in genetic equilibrium.

How closely related are these four E. minor populations? From an analysis of Nei's genetic identity values, it appears that the two southern populations from Motunau Island and Onawe Peninsular are the most similar. The population from Poor Knights Island is the most distant from these two southern populations and that from Maud Island is the less distant. This is consistent with the observation that population specific loci are found amongst the four penguin populations. Plasma EST-2 is found only in the Onawe and Motunau populations; and $L D H-3$ is only detected in the Poor Knights Island population. Thus, the genetic identity values also suggests a clinal pattern of divergence with the Onawe Peninsula and Motunau Island populations at one end of the cline and the Poor Knights population at the other. A comparison of Yellow-eyed Penguin with $E$. minor reveals a high degree of differentiation between the two genera. The Yellow-eyed Penguin has unique $C A$ and $L D H$ loci, and it lacks the red cell EST-6, $A L P-2$ and $L D H-3$ loci which are in all the Eudyptula minor populations.

Acknowledgements We thank Dr P. Harper for critical reading of the manuscript and Dr C. Challies for providing much help and advice on the penguins, the Wildlife Service for permits to handle the penguins and to visit Maud Island, and the Department of Lands and Survey for allowing our visit to Motunau Island. We are also grateful for help in the field provided by A. Meredith, M. Barth and P. Claman. 


\section{REFERENCES}

AVISE, J. C. AND AQUADRO, C. F. 1982. A summary of genetic distances in the vertebrates. In Hecht, M. K., Wallace, B. and Parnace, G. T. (eds.) Evolutionary Biology, 15, 151-180.

BREWER, G. J. 1970. An Introduction to Isozyme Techniques. Academic Press, London.

FERGUSION, A. 1980. Biochemical Systematics and Evolution. Blackie, Glasgow.

GILlESPIE, J. H. AND KOJIMA, K. 1968. The degree of polymorphism in enzymes involved in energy production compared to that in nonspecific enzymes in two Drosophila ananassae populations. Genetics, 61, 582-585.

HARRIS, H. AND HOPKINSON, D. A. 1976. Handbook of Enzymes Electrophoresis in Human Genetics. North-Holland, Amsterdam.
KINKSY, F. C. AND FALLA, R. A. 1976. A subspecific revision of the Australasian Blue Penguin (Edyptula minor) in the New Zealand area. Rec. Nat. Mus. N.Z., 1(7), 105-126.

MEREDITH, M. A. M. 1984. M.Sc. Thesis, University of Canterbury.

NEI, M. 1972: Genetic distance between populations. Amer. Nat., 106, 283-292.

O'BRIEN, P. J. 1940. Some observations on the breeding habits and general characteristics of the White Flippered Penguin (Eudyptula albosignata). Rec. Cant. Mus., 4, 311-324.

REILLY, P. N. AND BALMFORD, P. 1975. A breeding study of little penguins (Eudyptula minor) in Australia. In Stonehouse, B. (ed.) The Biology of Penguins. MacMillan, London.

SHAW, C. R. AND PRASAD, R. 1970. Starch gel electrophoresis of enzymes-a compilation of recipes. Biochem. Genet., 4, 297-320. 